\title{
FAKTOR-FAKTOR YANG MEMPENGARUHI PENGGUNAAN LAYANAN MOBILE BANKING
}

\author{
Syamsul Hadi \\ Novi \\ Universitas Islam Indonesia \\ hadisyamsul54@gmail.com ${ }^{1}$
}

\begin{abstract}
This research objectives is to know the influence of the ease of use, benefits, risks, security and the ease of access to the use of mobile banking. This research took 249 respondents of 265 questionnaires received. Respondents taken by accidental sampling, and analyzed using multiple regression of SPSS 17. This research showed that easiness of operation and usefulness are not significant. Risk, easiness of access and security are significant.
\end{abstract}

Keywords: mobile banking, ease of use, benefits, risks, security and the ease of access

\section{PENDAHULUAN}

Metode konvensional (manual) perbankan adalah nasabah datang ke bank untuk bertransaksi. Bila nasabah ingin melakukan transfer dana ke rekening lain di bank yang sama atau bank yang berbeda, mereka harus datang ke bank, mengisi blanko transfer dan mengantri untuk dilayani. Cara ini sangat tidak efisien, karena perlu waktu cukup banyak hanya untuk transfer. Alasan ini merupakan salah satu penyebab dari pihak bank menentukan penawaran layanan mobile banking. Mobile banking diharapkan dapat mengurangi ketidakpraktisan metode manual serta menawarkan kepraktisan.

Perkembangan teknologi informasi semakin canggih dan diminati oleh masyarakat luas. Teknologi dengan menggunakan media perangkat seluler serta internet, semakin canggih fitur-fiturnya telah ditawarkan oleh para pembuat media komunikasi tersebut. Pemanfaatan teknologi informasi ini menjadi suatu kebutuhan untuk mendukung perkembangan bisnis di sektor perbankan. Pemanfaatan teknologi secara tepat juga harus diperhatikan, untuk meminimalkan risiko operasional, agar perbankan mampu beroperasi lebih efisien.

Saat ini layanan perbankan sudah merupakan kebutuhan masyarakat, transaksi perbankan merupakan suatu 'keharusan'. Untuk memudahkan transaksi perbankan, ditawarkan suatu produk yang berfungsi mendukung berbagai kegiatan nasabah perbankan yaitu Mobile banking. Nasabah maupun bank sama-sama mendapatkan keuntungan dengan adanya mobile banking. Nasabah akan mendapatkan informasi perbankan secara cepat, efektif dan efisien, serta dapat mengurangi waktu tunggu nasabah dalam melakukan transaksi perbankan. Sementara bagi bank itu sendiri, produk dengan teknologi informasi semakin memudahkan mereka untuk mengurangi pekerjaan karyawan khususnya teller dan atau customer service.

Mobile banking merupakan salah satu layanan perbankan yang menerapkan teknologi informasi. Layanan ini menjadi peluang bagi bank untuk menawarkan nilai tambah kepada pelanggan. Mobile banking atau biasa disebut m-Banking merupakan suatu layanan perbankan yang diberikan oleh pihak bank untuk mendukung 
kelancaran dan kemudahan kegiatan perbankan. Keefektifan dan keefisienan nasabah untuk melakukan berbagai transaksi M-banking tidak akan berjalan, jika tidak didukung oleh telepon seluler dan internet. Setiap orang yang memiliki ponsel dapat memanfaatkan fasilitas ini, untuk bertransaksi di mana saja dan kapan saja dengan mudah. Adanya berbagai kemudahan layanan perbankan tersebut, diharapkan nasabah merasa puas dalam menggunakan berbagai macam jasa yang diberikan oleh pihak bank.

Kelemahan dari m-banking adalah ketergantungan terhadap ketersediaan jaringan seluler operator yang bersangkutan. Jika terjadi blankspot atau ketidaktersediaan jaringan, maka layanan m-banking tidak bisa dilakukan. Hal tersebut sebenarnya bukanlah tanggung jawab bank melainkan tanggung jawab penyedia operator seluler dan internet provider yang digunakan oleh nasabah untuk mengakses layanan $m$-banking.

Di Indonesia mobile banking bukanlah hal yang asing lagi, karena telah menjadi bagian dari inovasi perbankan dalam mengikuti persaingan bisnis global. Oleh karena itu, institusi-institusi perbankan berusaha memberikan kepuasan pelayanan kepada para nasabahnya dengan memberikan fasilitas perbankan, berupa layanan mobile banking untuk melakukan transaksi atau bisnis. Penggunaan jaringan seluler untuk kepentingan transaksi komersial (mobile commerce) dinilai cukup aman, karena identitas pengguna lebih jelas, satu nomor ponsel hanya digunakan oleh satu orang. Maka mobile banking terlihat lebih sukses perkembangannya di Indonesia.

Penggunaan mobile banking dinilai menguntungkan bagi pihak bank dan juga nasabah. Semua transaksi menjadi lebih praktis, efektif serta efisien. Suryo (2005) mengatakan kelebihan m-banking menggunakan jaringan pengaman ganda atau berlapis, yaitu dari operator yang menyediakan jaringan seluler dan jaringan perbankan itu sendiri, sehingga tidak perlu dikhawatirkan penggunaannya. Tetapi semakin banyak informasi pribadi yang harus diberikan dalam penggunaan m-banking, maka semakin tinggi kemungkinan nasabah untuk menolak menggunakan m-banking. Kondisi ini berakibat konsumen tidak dapat memaksimalkan manfaat dari penggunaan $m$-banking.

Rahmawati (2010) meneliti tentang pengaplikasian layanan mobile banking dengan menggunakan tiga variabel independen, yaitu: persepsi kemudahan penggunaan, persepsi manfaat dan kepercayaan konsumen. Penelitian ini menambahkan 2 independen variabel yaitu kemampuan akses dan risiko.

Penelitian ini bertujuan untuk mengetahui pengaruh variabel persepsi kemudahan pengunaan, persepsi manfaat, risiko, kemampuan akses, dan keamanan terhadap penggunaan mobile banking.

Hasil penelitian ini dapat memberikan masukan bagi manajemen untuk pengambilan keputusan tentang penggunaan mobile banking oleh nasabah, sehingga pihak bank dapat meningkatkan pelayanan jasa mobile banking.

\section{REVIEW LITERATUR DAN HIPOTESIS}

Perkembangan kemajuan teknologi saat ini sangat cepat, sehingga para ahli menyebut gejala ini sebagai suatu revolusi. Perubahan-perubahan yang terjadi, terutama disebabkan berbagai kemampuan dan potensi teknologi memungkinkan manusia untuk saling berhubungan seolah tanpa batasan jarak, waktu, jumlah, kapasitas dan kecepatan (www. vibiznews.com).

Teknologi Informasi adalah suatu teknologi yang digunakan untuk mengolah data, termasuk memproses, mendapatkan, menyusun, menyimpan memanipulasi data dalam berbagai cara untuk menghasilkan informasi yang berkualitas, yaitu informasi yang relevan, 
akurat dan tepat waktu. Pemanfaatannya untuk keperluan pribadi, bisnis, dan pemerintahan serta merupakan informasi strategis untuk pengambilan keputusan (www.wikipedia.com). Teknologi ini menggunakan seperangkat komputer untuk mengolah data, sistem jaringan untuk menghubungkan satu komputer dengan komputer lain sesuai dengan kebutuhan. Teknologi komunikasi digunakan agar data dapat disebar dan diakses secara global.

Penggunaan teknologi informasi di dalam sistem bank bertujuan untuk lebih menarik nasabah serta mempertahankan nasabah agar terus menggunakan layanan atau jasa yang diberikan pihak bank. Teknologi informasi juga memberikan keuntungan lain bagi bank karena dalam proses perbankan sendiri segala sesuatunya menjadi lebih praktis, termanajemen, efektif dan efisien.

\section{Konsep Mobile Banking}

Teknologi informasi ikut mewarnai dunia perbankan. Kehadiran sistem online yang ditangani oleh teknologi komputer dan teknologi komunikasi memungkinkan nasabah bertransaksi dari kantor cabang dari bank yang sama (atau secara terbatas dari bank berbeda) yang berada dimana saja. Pada perkembangan selanjutnya, sistem tersebut dilengkapi dengan mesin-mesin Anjungan Tunai Mandiri atau Automatic Teller Machine, biasa disebut dengan ATM. Melalui ATM memungkinkan nasabah bertransaksi tanpa harus bergantung oleh jam kerja bank. Tidak puas dengan model pelayanan seperti itu, pihak bank juga mengembangkan layanan dengan telepon selular, yang dikenal dengan mobile banking.

Rahardjo (2002) menjelaskan bahwa ada beberapa persyaratan dari mobile banking yaitu: Aplikasi mudah digunakan, Layanan dapat dijangkau dari mana saja, Murah, Aman dan Dapat diandalkan (reliable). Keunggulan mobile banking telah mengalami berbagai macam terapan teknologi canggih, perbaikan-perbaikan yang berarti, sehingga tidak perlu dikhawatirkan penggunaannya. Selain memiliki kelebihan, layanan ini juga mempunyai kelemahan yang justru datang dari aspek non teknis. Bahaya tersebut akan datang ketika orang lain, dalam hal ini pihak ketiga, mengetahui nomor PIN pengguna mobile banking. Kondisi ini akan berdampak tingkat kenyamanan nasabah berbanding terbalik dengan tingkat keamanan yang didapatkan oleh nasabah.

\section{Kemudahan Penggunaan}

Persepsi kemudahan memberikan indikasi bahwa suatu sistem dirancang bukan untuk menyulitkan pemakainya, tetapi justru mempermudah seseorang dalam menyelesaikan pekerjaannya. Dengan kata lain, seseorang yang menggunakan sistem akan bekerja lebih mudah dibandingkan dengan seseorang yang tidak menggunakan sistem atau bekerja secara manual.

Kemudahan penggunaan mobile banking memiliki makna bahwa layanan mobile banking oleh pihak bank akan mudah dipahami dan mudah untuk digunakan, sehingga nasabah dapat dengan mudah mempelajari tata cara bertransaksi menggunakan m-banking. Penerimaan penggunaan sebuah sistem juga turut dipengaruhi oleh kemudahan penggunaan sistem tersebut. Ini merupakan refleksi psikologis pengguna untuk lebih bersikap terbuka terhadap sesuatu yang mudah dipahami. Kemudahan tersebut dapat mendorong seseorang untuk menerima dan menggunakan sebuah sistem.

Persepsi kemudahan penggunaan diyakini memiliki pengaruh yang kuat dalam pembentukan sikap seorang individu dalam menerima sebuah teknologi. Davis (1989) memberikan beberapa indikator kemudahan terhadap suatu sistem informasi (termasuk mobile banking) yaitu: mudah dipelajari dan dioperasikan, mengerjakan dengan mudah apa yang diinginkan oleh pengguna, dan menambah keterampilan para pengguna. Semakin mudah suatu sistem untuk 
dipelajari dan digunakan, maka hal tersebut akan meningkatkan minat nasabah untuk menggunakan mobile banking.

Intensitas penggunaan dan interaksi pengguna dengan sistem juga dapat menunjukkan kemudahan penggunaan. Suatu sistem yang lebih sering digunakan dapat menunjukkan bahwa sistem tersebut lebih dikenal, lebih mudah dioperasikan, dan lebih mudah digunakan oleh pemakainya. Hal ini disebabkan pemakai atau nasabah terbuka terhadap sesuatu yang dapat dipahami dengan mudah.

Auliani (2008) menyimpulkan bahwa Persepsi kemudahan penggunaan tidak berpengaruh terhadap penggunaan mobile banking. Hal itu dapat terjadi karena seseorang tidak terlalu mempermasalahkan kemudahan penggunaan suatu sistem, pada saat ia menggunakan sistem tersebut. Para nasabah tidak begitu mempermasalahkan kemudahan penggunaan mobile banking, karena pada saat ini pelanggan atau masyarakat sudah memiliki banyak pengetahuan. Mereka sudah mengerti tentang teknologi, HP, dan komputer. Mereka beranggapan bahwa penggunaan mobile banking sekarang sudah mudah karena teknologi sudah semakin berkembang dari tahun ke tahun, mereka merasa bahwa mobile banking mudah untuk digunakan. Mudah atau tidaknya sistem mobile banking digunakan, tidak berpengaruh terhadap keputusan nasabah untuk menggunakan layanan mobile banking ataupun tidak menggunakan.

$\mathrm{H}_{1}$ : Persepsi kemudahan penggunaan berpengaruh positif terhadap penggunaan mobile banking.

\section{Manfaat}

Layanan mobile banking akan bermanfaat jika layanan tersebut mudah dimengerti serta mampu menjalin interaksi dengan penggunanya. Bank menyediakan layanan seperti cek saldo, transfer antar rekening, info kurs dan sebagainya dalam mobile banking, dengan tujuan memberi kemudahan bagi nasabahnya untuk bertransaksi. Penggunaan mobile banking bagi nasabah dapat menghemat waktu dan biaya (biaya transportasi), karena nasabah tidak harus mendatangi bank secara langsung hanya sekedar untuk melakukan transaksi, karena mobile banking memberi pelayanan selama 24 jam. Nasabah dapat melakukan transaksi kapanpun dan dimanapun bahkan ketika kantor bank sudah tutup.

Seseorang menggunakan mobile banking apabila orang tersebut percaya bahwa mobile banking dapat memberikan manfaat terhadap pekerjaannnya dan pencapaian prestasi kerjanya. Para nasabah berharap memperoleh manfaat, pada saat nasabah melaksanakan tugas dan pekerjaan rutinnya setelah ia menggunakan mobile banking . Pengukuran kemanfaatan tersebut dilihat berdasarkan frekuensi penggunaan aplikasi yang dijalankan. Oleh karena itu tingkat kemanfaatan mobile banking akan mempengaruhi sikap nasabah terhadap sistem tersebut.

Kemanfaatan bagi nasabah meliputi membuat pekerjaan lebih mudah, menambah produktivitas, mempertinggi efektifitas, dan mengembangkan kinerja pekerjaan. Kemanfaatan yang meningkatkan kinerja akan berdampak terhadap penggunaan teknologi. Berdasarkan pengertian ini, manfaat penggunaan TI dapat diketahui dari kepercayaan pengguna TI pada saat memutuskan penerimaan TI. Tentunya dasar kepercayaan bahwa penggunaan TI tersebut memberikan kontribusi positif bagi penggunanya, bisa dirasakan. Seseorang mempercayai dan merasakan bahwa dengan menggunakan komputer dan HP sangat membantu dan mempertinggi prestasi kerja yang akan dicapainya, atau dengan kata lain orang tersebut mempercayai penggunaan TI telah memberikan manfaat terhadap pekerjaan dan pencapaian prestasi kerjanya.

$\mathrm{H}_{2}$ : Persepsi manfaat berpengaruh positif terhadap penggunaan mobile banking. 


\section{Risiko}

Risiko adalah sesuatu ketidakpastian yang dipertimbangkan orang untuk memutuskan atau tidak melakukan transaksi secara online. Dapat dikatakan bahwa transaksi online memiliki risiko tinggi, karena nasabah tidak dapat melakukan transaksi secara tatap muka dan mereka juga tidak dapat memastikan apakah transaksi yang telah dilakukannya, telah diproses secara tepat waktu atau tidak. Sebelum menggunakan layanan mobile banking, nasabah pasti telah mempertimbangkan kemungkinan berbagai risiko. Seperti, risiko bocornya PIN dan data pribadi nasabah, risiko dari serangan virus, risiko salah kirim, atau bahkan nasabah melakukan salah ketik. Namun, semua risiko tersebut dapat diminimalisir, baik dari pihak bank ataupun dari nasabahnya. Untuk memcegah terjadinya kebocoran PIN dan data pribadi, maka pihak bank dapat memberikan pengamanan yang berlapislapis agar pihak ke tiga tidak dapat mencuri data nasabah. Sedangkan, untuk mengurangi risiko salah kirim maupun salah ketik, nasabah dapat melakukan pengecekan ulang (membaca ulang) sebelum dikirim. Semakin besar risiko yang akan ditanggung nasabah dalam menggunakan layanan sistem mobile banking, maka semakin rendah penggunaan sistem tersebut.

Risiko didefinisikan sebagai persepsi nasabah atas ketidakpastian dan konsekuensi yang akan dihadapi setelah melakukan aktivitas tertentu. Risiko berhubungan dengan sistem keamanan pada layanan mobile banking. Saat keamanan dalam sistem tersebut lemah, maka hal ini dapat membuat nasabah cemas dan ragu untuk memberikan nomor rekening mereka dan informasi penting lainnya melalui sistem layanan mobile banking. Nasabah khawatir jika kerahasiaan nomor PIN diketahui oleh orang lain tanpa sepengetahuan mereka, sehingga menyebabkan rendahnya keinginan nasabah untuk menggunakan layanan mobile banking tersebut. Amijaya (2010) menyimpulkan bahwa semakin tinggi persepsi risiko nasabah akan menurunkan minat nasabah dalam menggunakan mobile banking.

$\mathrm{H}_{3}$ : Risiko berpengaruh negatif terhadap penggunaan mobile banking.

\section{Kemampuan Akses}

Semakin majunya teknologi informasi dan komunikasi dewasa ini, membuat nasabah semakin menuntut tersedianya fasilitas dan kecepatan akses, aman, mudah dan nyaman guna melakukan transaksi perbankan mereka. Banyak bank memahami perkembangan tren tersebut dan terus meningkatkan fasilitas perbankan transaksionalnya.

Kemampuan akses meliputi akses secara fisik (infrastruktur) dan kemampuan menggunakan sistem. Karahanna et.all (1999) menyatakan bahwa jika informasi sistem dapat semakin mudah untuk diakses, maka semakin sedikit usaha yang diperlukan untuk menggunakan sistem tersebut. Dalam konteks mobile banking, kemampuan akses tidak hanya kemampuan nasabah dalam menggunakan sistem, tetapi juga kemampuan akses internet dan HP secara fisik. Adanya infrastruktur teknologi yang memadai, aplikasi pemasaran melalui internet dan HP, seperti mobile banking akan dapat dikerjakan dengan lebih mudah. Tan dan Teo (2000) menyatakan bahwa kemampuan akses mobile banking merupakan fasilitator dalam pengadopsian karena kapasitas mobile banking mendorong pengguna untuk mempersepsikan teknologi menjadi lebih baik.

$\mathrm{H}_{4}$ : Kemampuan akses berpengaruh positif tehadap penggunaan mobile banking.

\section{Keamanan}

Keamanan adalah persepsi nasabah terhadap kemampuan bank untuk melindungi informasi personal yang didapat dari transaksi elektronik terhadap pengguna yang tidak berwenang. Keamanan transaksi elektronik membuat nasabah merasa yakin bahwa 
kerahasiaan data pribadinya terjamin saat bertransaksi melalui mobile banking.

Keamanan data merupakan hal yang penting diperhatikan dalam menggunakan layanan mobile banking. Dalam transaksi online, risiko hilangnya kerahasiaan merupakan faktor signifikan yang mempengaruhi kepercayaan dan penggunaan. Sudah banyak survei yang menemukan adanya kekhawatiran yang tinggi dari nasabah tentang kerahasiaan data pribadi mereka saat bertransaksi secara online (Maharsi dan Fenny, 2006). Kekhawatiran utama bagi pengguna mobile banking adalah kurangnya pengendalian terhadap kerahasiaan informasi yang mengakibatkan penyalahgunaan data pribadi.

Pihak penyedia layanan mobile banking harus dapat menjamin keamanan data nasabah. Bank harus menyediakan teknologi keamanan data yang sesuai standar, sehingga data pelanggan tidak dapat dicuri dan disalahgunakan oleh orang yang tidak bertanggungjawab. Sistem maupun jaringan mobile banking telah menggunakan pengamanan yang seoptimal mungkin. Kondisi pengamanan mobile banking juga selalu dipantau dan ditingkatkan, sejalan dengan perkembangan teknologi dan ancaman yang ada. Adanya jaminan keamanan dari pihak bank akan menimbulkan rasa percaya serta menarik minat nasabah untuk menggunakan mobile banking.

Keamanan berpengaruh positif terhadap penggunaan mobile banking. Implikasinya adalah jika konsumen percaya bahwa saluran pembayaran di mobile banking tidak aman, hal ini megurangi kepercayaan konsumen. Akibatnya mereka malas melakukan transaksi online banking (Maharsi dan Fenny, 2006). Bank akan dipercaya oleh nasabahnya, jika mampu meyakinkan nasabahnya bahwa keamanan dan kerahasiaan data-data nasabah terjamin. Jika nasabah sudah percaya bahwa saluran pembayaran di internet aman, serta percaya bahwa pihak bank tidak akan membocorkan informasi rahasia personal mereka atau menjualnya pada pihak lain tanpa mengkonsultasikannya terlebih dahulu, maka kondisi ini merupakan daya tarik minat calon nasabah untuk menggunakan mobile banking.

$\mathrm{H}_{5}$ : Keamanan berpengaruh positif terhadap penggunaan mobile banking.

\section{METODE PENELITIAN}

\section{Populasi dan Sampel}

Populasi penelitian ini adalah semua individu yang menggunakan layanan mobile banking. Sampel diperoleh dari individu pengguna mobile banking yang kebetulan ditemui oleh peneliti (accidental sampling) dan bersedia untuk menjadi responden. Data dikumpulkan dengan menggunakan kuesioner. Kuesioner disebar melalui web, jejaring sosial, dan dibagikan secara langsung. Jawaban kuesioner diperoleh selama hampir dua bulan yang ditutup pada akhir Maret 2014. Jumlah jawaban kuesioner yang masuk sebanyak 265 buah, namun terdapat beberapa kuesioner tidak lengkap diisi. Jawaban kuesioner yang bisa diproses sebanyak 249 buah.

\section{Deskripsi Responden}

Berdasarkan jawaban kuesioner dari responden sebanyak 249, diperoleh 49,8\% di antaranya berjenis kelamin laki-laki. Kondisi tersebut menunjukkan bahwa mobile banking digunakan oleh semua kalangan baik laki-laki maupun perempuan dengan komposisi hampir sebanding. Kemajuan teknologi yang sangat pesat bisa dinikmati oleh semua kalangan tanpa ada bias gender. Mayoritas responden berusia 20-30 tahun (222 orang atau 89,2\%). Kisaran usia ini merupakan tahap awal kerja atau karier dan mereka biasanya bertugas sebagai pelaksana lapangan, sehingga dengan adanya teknologi mobile banking ini mereka sangat terbantu. 
Tabel 1

Hasil Deskriptif Statistik

\begin{tabular}{|l|r|r|r|r|r|}
\hline & PKP & \multicolumn{1}{c|}{ PM } & \multicolumn{1}{c|}{ RISK } & KAK & AMAN \\
\hline Mean & 4.0128 & 4.2369 & 3.9611 & 4.0455 & 4.1084 \\
\hline $\begin{array}{l}\text { Standard } \\
\text { Error }\end{array}$ & 0.0504 & 0.0444 & 0.0581 & 0.0515 & 0.0531 \\
\hline Median & 4.2 & 4.25 & 4 & 4 & 4.3333 \\
\hline $\begin{array}{l}\text { Standard } \\
\text { Deviation }\end{array}$ & 0.7954 & 0.7017 & 0.9171 & 0.8135 & 0.8394 \\
\hline Kurtosis & 0.6287 & 1.8109 & -0.3393 & 0.4140 & -0.8753 \\
\hline Skewness & -0.8409 & -1.1787 & -0.6385 & -0.7956 & -0.5784 \\
\hline Minimum & 1 & 1 & 1 & 1 & 2 \\
\hline Maximum & 5 & 5 & 5 & 5 & 5 \\
\hline
\end{tabular}

Sumber: hasil olah data

Dari tabel 1 dapat diketahui bahwa nilai rata-rata semua independen variabel memiliki nilai yang tinggi, yaitu di atas 4 dari skor maksimum 5. Nilai tertinggi pada persepsi manfaat yaitu sebesar 4,2369 dan sebaliknya nilai terendah ada pada risiko yaitu sebesar 3,9611. Nilai ini menunjukkan lebih banyak responden yang menyatakan bahwa layanan mobile banking bermanfaat dan bahkan sangat bermanfaat. Nilai rata-rata terendah adalah pada variabel risiko dengan nilai 3,9611; walaupun nilainya mendekati 4 tetapi dibanding variabel lainnya responden mengatakan nilai risiko adalah yang paling kecil, sehingga tidak terlalu berpengaruh terhadap penggunaan mobile banking. Kondisi ini bisa dianggap wajar, karena sebagian risiko dapat dikelola atau diminimalisir oleh nasabah.

\section{Uji Validitas dan Reliabilitas}

Pengujian validitas dan reliabilitas dalam penelitian ini dilakukan dengan menggunakan bantuan komputer menggunakan program SPSS for Windows. Kriteria valid adalah 0,5 dan Cronbach's Alpha menggunakan tabel berikut:

\section{Tabel 2}

\section{Kriteria Reliabilitas}

\begin{tabular}{|l|l|}
\hline \multicolumn{1}{|c|}{ Cronbach's alpha } & \multicolumn{1}{c|}{ Internal consistency } \\
\hline$\alpha>0.9$ & Excellent (Sangat Baik) \\
\hline $0.7<\alpha<0.9$ & Good (Bagus) \\
\hline $0.6<\alpha<0.7$ & Acceptable (Bisa diterima) \\
\hline $0.5<\alpha<0.6$ & Poor (Kurang) \\
\hline$\alpha<0.5$ & Unacceptable (Tidak bisa diterima) \\
\hline
\end{tabular}

Sumber: George, D., \& Mallery, P (2003) berikut:

Adapun hasil pengujian adalah sebagai

\section{Tabel 3}

Hasil Uji Validitas dan Reliabilitas

\begin{tabular}{|c|c|c|c|c|}
\hline Pertanyaan & Correlation & Status & $\begin{array}{l}\text { Cronbach's } \\
\text { Alpha }\end{array}$ & Status \\
\hline$\frac{\overline{P K P 1}}{\mathrm{P}}$ & 0,669 & Valid & \multirow{3}{*}{0,818} & \multirow{3}{*}{ Bagus } \\
\hline $\begin{array}{ll}\mathrm{C}^{2} \mathrm{C} \\
\mathrm{P}\end{array}$ & $\frac{0.012}{0.602}$ & $\begin{aligned} \text { Valide } \\
\text { Val }\end{aligned}$ & & \\
\hline$\frac{\mathrm{PKP} 4}{\mathrm{PK} 5}$ & 0.564 & $\begin{array}{l}\text { Valio } \\
\text { Vali }\end{array}$ & & \\
\hline PMI & 0.630 & Valic & \multirow{3}{*}{0,787} & \multirow{3}{*}{ Bagus } \\
\hline$\frac{\mathrm{PM2}}{\mathrm{P}}$ & $\frac{0.572}{0.660}$ & $\begin{array}{l}\text { Valic } \\
\text { Vac }\end{array}$ & & \\
\hline PM4 & 0.533 & Valid & & \\
\hline Risk1 & 0.739 & Valid & \multirow{2}{*}{0,876} & \multirow{2}{*}{ Bagus } \\
\hline$\frac{\operatorname{Risk2}}{\operatorname{Ris} 33}$ & $\frac{0,812}{0,734}$ & Valid & & \\
\hline $\mathrm{CAK}$ & 0.620 & Valide & \multirow[b]{2}{*}{0,808} & \multirow[b]{2}{*}{ Bagus } \\
\hline$\frac{\mathrm{KAK2}}{\mathrm{KAK}}$ & $\frac{0.687}{0.666}$ & $\begin{array}{l}\text { Valic } \\
\text { Valo }\end{array}$ & & \\
\hline Keamananl & $\frac{0.000}{0.677}$ & $\begin{array}{l}\text { Valio } \\
\text { Valio }\end{array}$ & \multirow[b]{2}{*}{0,772} & \multirow{3}{*}{ Bagus } \\
\hline Keamanan2 & $\frac{0.574}{0.577}$ & Valid & & \\
\hline $\begin{array}{l}\text { Keamanans } \\
\text { PMB1 }\end{array}$ & & & \multirow{3}{*}{0,840} & \\
\hline $\mathrm{PMB2}$ & 0.699 & Valid & & \multirow{2}{*}{ Bagus } \\
\hline PMB3 & 0,728 & Valid & & \\
\hline
\end{tabular}

Sumber: hasil olah data

Berdasarkan tabel 3 di atas dapat disimpulkan bahwa seluruh item pertanyaan dalam kuesioner di semua variabel adalah valid dan reliabel.

\section{Uji Multikolinearitas}

Hasil pengujian multikolinearitas menggunakan SPSS adalah sebagai berikut:

\section{Tabel 4}

Hasil Pengujian Multikolinearitas

\begin{tabular}{|c|c|c|}
\hline & Tolerance & VIF \\
\hline $\begin{array}{c}\text { Persepsi kemudahan } \\
\text { penggunaan }\end{array}$ & 0,464 & 2,156 \\
\hline Persepsi manfaat & 0,551 & 1,814 \\
\hline Risiko & 0,394 & 2,540 \\
\hline Kemampuan akses & 0,506 & 1,977 \\
\hline Keamanan & 0,442 & 2,261 \\
\hline
\end{tabular}

Sumber: hasil olah data

Dilihat dari nilai VIF pada hasil pengujian di atas, nilai VIF jauh lebih kecil dari 10. Dengan demikian, dapat disimpulkan bahwa model regresi tersebut tidak mempunyai indikasi masalah multikolinearitas, sehingga semua variabel bebas dapat dimasukkan ke dalam penelitian ini dan model regresi tersebut layak dipakai. 


\section{Model Summary}

\begin{tabular}{|c|c|c|c|c|}
\hline Model & $\mathrm{R}$ & R Square & $\begin{array}{l}\text { Adjusted R } \\
\text { Square }\end{array}$ & Std. Error of the Estimate \\
\hline 1 & $.805^{\mathrm{a}}$ & .649 & .641 & .57521 \\
\hline
\end{tabular}

\section{ANOVA $^{b}$}

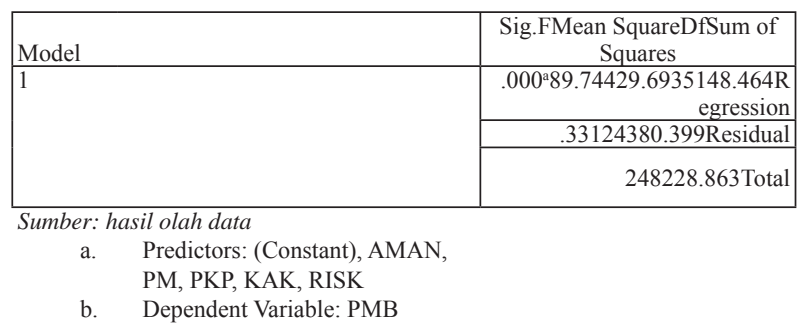

\section{Analisis Regresi Berganda}

Berikut ini adalah tabel hasil uji regresi linier berganda secara keseluruhan.

\section{Tabel 5}

Hasil Analisis Regresi Berganda Model Summary

\begin{tabular}{|c|c|c|c|c|}
\hline Model & R & R Square & $\begin{array}{c}\text { Adjusted R } \\
\text { Square }\end{array}$ & $\begin{array}{c}\text { Std. Error } \\
\text { of the } \\
\text { Estimate }\end{array}$ \\
\hline 1 & $.805^{\mathrm{a}}$ & .649 & .641 & .57521 \\
\hline
\end{tabular}

Sumber: hasil olah data

a. Predictors: (Constant), AMAN, PM, PKP, KAK, RISK

b. Dependent Variable: PMB

ANOVA $^{b}$

\begin{tabular}{|l|l|r|r|r|c|c|}
\hline \multicolumn{2}{|l|}{ Model } & $\begin{array}{r}\text { Sum of } \\
\text { Squares }\end{array}$ & Df & $\begin{array}{c}\text { Mean } \\
\text { Square }\end{array}$ & F & Sig. \\
\hline 1 & Regression & 148.464 & 5 & 29.693 & 89.744 & $.000^{\mathrm{a}}$ \\
& Residual & 80.399 & 243 & .331 & & \\
\hline & Total & 228.863 & 248 & & & \\
\hline
\end{tabular}

Sumber: hasil olah data

a. Predictors: (Constant), AMAN, PM, PKP, KAK, RISK

b. Dependent Variable: PMB
Coefficients $^{\mathrm{a}}$

\begin{tabular}{|c|c|c|c|c|c|c|}
\hline & & \multicolumn{2}{|c|}{$\begin{array}{l}\text { Unstandardized } \\
\text { Coefficients }\end{array}$} & \multirow{2}{*}{\begin{tabular}{c|}
$\begin{array}{c}\text { Standardized } \\
\text { Coefficients }\end{array}$ \\
Beta
\end{tabular}} & \multirow[b]{2}{*}{$\mathrm{t}$} & \multirow[b]{2}{*}{ Sig. } \\
\hline \multicolumn{2}{|c|}{ Model } & $\mathrm{B}$ & Std. Error & & & \\
\hline \multirow[t]{6}{*}{1} & (Constant) & -.118 & .243 & & -.485 & .628 \\
\hline & PKP & .038 & .067 & .031 & .556 & .579 \\
\hline & PM & .017 & .070 & .012 & .242 & .809 \\
\hline & RISK & -364 & .063 & .348 & 5.738 & .000 \\
\hline & KAK & .132 & .063 & .112 & 2.087 & .038 \\
\hline & AMAN & .475 & .065 & .415 & 7.265 & .000 \\
\hline \multicolumn{7}{|c|}{$\begin{array}{l}\text { Sumber: hasil olah data } \\
\text { a. Dependent Variable: PMB } \\
\text { b. Sumber : data diolah, } 2014\end{array}$} \\
\hline
\end{tabular}

Dari tabel 5 diketahui bahwa nilai Adjusted $R$ Square adalah $64,1 \%$, berarti $64,1 \%$ dari perubahan variabel terikat dapat dijelaskan oleh variabel bebas, sehingga kemampuan menjelaskan per variabel rata-rata adalah $12,82 \%$. Lima variabel yang digunakan pada penelitian ini hanyalah sebagian kecil saja dari sekian banyaknya variabel pengaruh penggunaan mobile banking. Penelitian ini mampu menjelaskan sebesar $64,1 \%$ atau rata-rata $12,82 \%$ per variabel, maka dapat disimpulkan bahwa penelitian ini cukup baik.

Nilai F sebesar 89,744 dengan Significance $F$ sebesar 0,000 menunjukkan tingkat kesalahan yang akan ditanggung jika model dikatakan baik. Kecilnya nilai signifikansi $\mathrm{F}$ menunjukkan model yang diajukan baik, karena memiliki kemungkinan kesalahan sangat kecil (karena kurang dari 1\%). Kesimpulan dari indikator ini adalah bahwa model dalam penelitian ini dapat digunakan untuk analisis lebih lanjut.

Nilai signifikansi konstanta bernilai $62,8 \%$ yang berarti tidak signifikan. Hal ini menunjukkan tidak ada variabel yang terlewat dalam model (Hadi, 2009). Dari hasil di atas menunjukkan bahwa secara keseluruhan model dinyatakan cukup baik karena erornya kecil dan tidak ada variabel yang terlewat. 


\section{Uji Variabel Bebas}

Koefisien $(\beta)$ variabel persepsi kemudahan penggunaan $\left(\mathrm{X}_{1}\right)$ pada Tabel 5 adalah 0,038 dan memilki significance sebesar 0,579 atau 57,9\%. Dari angka-angka tersebut dapat disimpulkan bahwa persepsi kemudahan penggunaan tidak signifikan mempengaruhi penggunaan mobile banking, maka hipotesa null tidak ditolak. Hal ini menunjukkan bahwa kemudahan penggunaan tidak berpengaruh tehadap penggunaan mobile banking.

Para nasabah tidak mempermasalahkan kemudahan penggunaan mobile banking, kondisi ini wajar, karena pada saat ini pelanggan atau nasabah sudah memiliki banyak pengetahuan. Mereka sudah mengerti tentang teknologi, HP dan komputer. Mereka beranggapan bahwa penggunaan mobile banking mudah digunakan, karena teknologi semakin berkembang dari tahun ke tahun. Mudah atau tidaknya sistem mobile banking digunakan, tidak mempengaruhi keputusan nasabah untuk menggunakan layanan mobile banking.

Hasil penelitian ini sejalan dengan hasil penelitian Nur Auliani (2008), yang memiliki significance sebesar 19,8\%, Rizki Amalia (2009) 26,5\%, Yulia Rahmawati (2010) 53,3\%. Dari data tersebut menunjukkan bahwa dari tahun ke tahun tingkat signifikansinya semakin rendah (semakin tidak berpengaruh). Semakin tinggi nilai probabilitas signifikansi variabel menunjukkan variabel semakin tidak signifikan. Masyarakat ataupun nasabah bank pada saat ini semakin 'melek' teknologi layanan mobile banking. Alasan lain sebagai penyebab tidak signifikan adalah mayoritas pengguna layanan mobile banking telah menggunakannya minimal selama 1 (satu) tahun, sehingga para nasabah sudah terbiasa (tidak merasa kesulitan lagi) dalam menggunakan layanan mobile banking. Kemudahan atau kesulitan yang diberikan oleh layanan mobile banking tidak akan mengurangi penggunaan mobile banking. Artinya persepsi kemudahan dalam menggunakan mobile banking tidak akan mempengaruhi pemakai untuk menggunakan sistem tersebut.

Hasil penelitian ini tidak sejalan dengan hasil penelitian Adam (1992) yang menyatakan bahwa suatu sistem yang lebih sering digunakan dapat menunjukkan bahwa sistem tersebut sudah dikenal, lebih mudah dioperasikan dan lebih mudah digunakan. Perbedaan hasil penelitian ini dikarenakan Adam (1992) meneliti pada saat masyarakat belum 'melek' teknologi, HP harganya masih mahal jadi penggunanyapun masih sedikit. Di masa sekarang segala sesuatu yang sulit dapat menjadi mudah dan bisa dilakukan oleh siapa saja karena adanya kemajuan teknologi.

Penelitian selanjutnya tidak perlu menyertakan variabel persepsi kemudahan, karena besar kemungkinan hasil yang didapat akan semakin tidak signifikan. Variabel ini dapat diganti dengan variabel lain.

Persepsi manfaat $\left(\mathrm{X}_{2}\right)$ memiliki sebesar 0,017 dan significance sebesar 0,809 atau 80,9\%. Dari angka-angka tersebut dapat disimpulkan bahwa persepsi manfaat tidak signifikan berpengaruh terhadap penggunaan mobile banking. Hal ini menunjukkan bahwa hipotesa null tidak ditolak.

Apabila seseorang merasakan manfaat atas suatu layanan, maka ia akan menggunakan layanan tersebut dan begitupun sebaliknya. Dari hasil penelitian ini data yang diperoleh tidak sesuai dengan logika tersebut. Jika dilihat dari nilai rata-rata persepsi manfaat yaitu sebesar 4,2 dari nilai maksimal 5, maka hal ini menunjukkan bahwa mobile banking sangat bermanfaat bagi nasabah dan mereka menilai manfaat atas mobile banking sangat tinggi. Nilai standar deviasi menunjukkan nilai yang sangat rendah yaitu 0,7018 menunjukkan bahwa semua responden merasakan manfaat yang besar atas mobile banking atau tidak ada responden yang berpendapat bahwa m-banking tidak bermanfaat. Rendahnya standar deviasi berakibat pada data sangat homogen 
dan secara langsung tidak berpengaruh secara signifikan terhadap penggunaan mobile banking. Dengan demikian, variabel persepsi manfaat tidak berpengaruh terhadap penggunaan mobile banking, bukan disebabkan tidak dirasakannya manfaat oleh responden, tetapi lebih disebabkan oleh tingginya manfaat yang dirasakan oleh responden itu sendiri.

Hasil penelitian ini sejalan dengan hasil penelitian Rahadianto (2009), namun tidak sejalan dengan hasil penelitian Rosita (2011) yang menyatakan bahwa semakin nasabah merasakan manfaat sistem akan menarik minat untuk menggunakan sistem tersebut. Perbedaan hasil ini karena adanya perbedaan proksi.

Saran yang dapat diberikan untuk penelitian selanjutnya adalah tidak perlu menyertakan variabel persepsi manfaat atau mengganti dengan proksi lain.

Tabel 5. menunjukkan koefisien $(\beta)$ atas variabel risiko $\left(\mathrm{X}_{3}\right)$ adalah $-0,364$ dan memiliki nilai significance sebesar 0,000 . Dapat disimpulkan bahwa hipotesa risiko berpengaruh secara negatif signifikan kuat terhadap penggunaan mobile banking. Hasil ini menunjukkan bahwa hipotesa null ditolak.

Risiko penggunaan mobile banking besar, maka akan mengurangi nasabah untuk menggunakan mobile banking. Sebaliknya, jika risiko yang terkandung dalam mobile banking kecil, maka akan meningkatkan nasabah untuk menggunakan layanan pada sistem tersebut. Kondisi ini terjadi karena adanya kekhawatiran dari para nasabah saat menggunakan sistem tersebut. Para nasabah tentu tidak akan mau menggunakan sistem tersebut jika konsekuensi yang akan ditanggungnya besar, karena hal itu dapat merugikan mereka. Dapat dikatakan bahwa dunia online adalah dunia yang penuh ketidakpastian dan mempunyai konsekuensi tinggi, karena transaksi tidak dilakukan secara tatap muka. Untuk mengatasinya, pihak bank harus memberikan tingkat keamanan terhadap sistem mobile banking, sehingga dengan usaha pihak bank dalam memperkecil risiko tersebut, mampu memotivasi nasabah untuk menggunakan mobile banking.

Penelitian ini sejalan dengan hasil penelitian Amijaya (2010), namun berbeda dengan hasil penelitian Riganaldhy (2009) yang menyatakan bahwa risiko tidak berpengaruh terhadap penggunaan mobile banking. Perbedaan hasil penelitian Reganaldhy (2009) karena melihat persepsi pengguna atas risiko yang ditimbulkan berasal dari risiko fisik dan risiko finansial. Sedangkan dalam penelitian ini hanya melihat persepsi pengguna atas risiko finansial dari penggunaan sistem mobile banking tersebut

Saran untuk penelitian selanjutnya adalah sebaiknya dalam kuesioner ditambahkan pernyataan mengenai penilaian risiko waktu, seperti ketepatan waktu dari pihak bank dalam setiap proses transaksi pada saat menggunakan mobile banking, sehingga pada saat melakukan transfer uang akan terkirim ke nomor rekening tujuan bisa dipastikan tepat waktu.

Koefisien $(\beta)$ atas variabel kemampuan akses $\left(\mathrm{X}_{4}\right)$ adalah 0,132 dan memilki significance sebesar 0,038 atau 3,8\%. Dari nilai tersebut dapat disimpulkan bahwa kemampuan akses berpengaruh positif signifikan moderat terhadap penggunaan mobile banking, maka hipotesa null ditolak. Hal ini menunjukkan bahwa kemampuan akses berpengaruh positif moderat terhadap penggunaan mobile banking.

Kemampuan akses berpengaruh terhadap penggunaan mobile banking tetapi variabel ini adalah variabel eksogen bagi bank, bank tidak bisa mengakses variabel ini. Tetapi bank tidak bisa tutup mata, karena yang dijual bank itu adalah layanan yang dapat diakses dengan mudah. Jika layanan bagus maka ada kemungkinan nasabah untuk menggunakan layanan tersebut. Sebaliknya jika layanan jelek maka bank tidak bisa menjual layanan bank tersebut kepada nasabah. Kemampuan akses 
dapat berupa kualitas jaringan, kualitas layanan baik di dalam maupun di luar ruangan, sambungan tidak terputus-putus, harga yang harus dibayar untuk mendapatkan akses dalam menggunakan jaringan dalam layanan kepada nasabah, serta kualitas pertukaran informasi antara pelanggan dan operator. Hal ini menunjukkan bahwa keseluruhan kemampuan akses dengan layanan yang disediakan ditimbulkan oleh seberapa jauh nasabah melihat layanan ini bermanfaat secara pribadi.

Hasil penelitian ini sejalan dengan Pribadi (2010), namun tidak sejalan dengan Negash (2003). Perbedaan tersebut dapat dimaklumi, karena Negash (2003) melakukan penelitian di Amerika Serikat, sehingga mereka mengabaikan kemampuan akses yang memang sudah sangat tinggi. Lain halnya dengan masyarakat Indonesia yang menginginkan sistem tersebut memberikan nilai lebih bagi mereka.

Dalam penelitian ini terdapat kelemahan, yaitu kurang dicantumkannya pernyataan tentang kualitas jaringan provider yang digunakan oleh nasabah dan petunjuk layanan untuk mengakses layanan mobile banking.

Saran yang dapat diberikan untuk penelitian selanjutnya adalahuntukmeminimalisir adanya kesalahan dalam mengakses layanan mobile banking, sebaiknya dalam kuesioner ditambahkan pernyataan adanya penjelasan dari pihak bank mengenai cara mengakses layanan mobile banking.

Koefisien ( $\beta$ ) atas variabel persepsi keamanan $\left(\mathrm{X}_{5}\right)$ adalah 0,475 dan significance sebesar 0,000. Dari angka-angka tersebut dapat disimpulkan bahwa persepsi keamanan mempunyai pengaruh positif dan signifikan kuat. Hal ini menunjukkan bahwa hipotesa null ditolak.

Hubungan positif antara keamanan dengan penggunaan layanan mobile banking menunjukkan bahwa semakin tinggi persepsi keamanan oleh nasabah, maka ia akan lebih tinggi menggunakan layanan mobile banking. Semakin nasabah merasa terjamin akan keamanan bertransaksi melalui mobile banking maupun kerahasiaan data-data pribadi maka akan semakin tinggi pula pengaruhnya terhadap penggunaan layanan tersebut.

Hasil penelitian ini sejalan dengan dilakukan Maharsi dan Fenny (2006). Penelitian ini tidak sejalan dengan Herna (2009) yang menyatakan bahwa hubungan antara keamanan dengan keinginan nasabah untuk menggunakan mobile banking adalah berbanding terbalik. Semakin tinggi keamanan yang disediakan pihak bank semakin rendah keinginan nasabah untuk menggunakan mobile banking. Perbedaan hasil ini dikarenakan Herna (2009) meneliti kekhawatiran akan keamanan dalam menggunakan mobile banking dan memberikan informasi personal saat bertransaksi, sedangkan pada penelitian ini meneliti tentang keamanan penggunaan mobile banking secara transaksi keuangan dan kepercayaan terhadap mobile banking dalam melindungi privasi nasabah.

Sebaiknya dalam kuesioner ditambahkan pernyataan mengenai persepsi nasabah tentang jaminan bahwa pihak bank tidak akan melakukan penyalahgunaan terhadap kerahasiaan informasi nasabah dalam bertransaksi.

\section{KESIMPULAN DAN SARAN}

\section{Kesimpulan}

Setelah dilakukan analisis penelitian terhadap 249 kuesioner yang memenuhi syarat, maka disimpulkan bahwa:

1. Persepsi nasabah Keamanan berpengaruh positif signifikan kuat terhadap mobile banking.

2. Persepsi nasabah atas Risiko berpengaruh negatif signifikan kuat terhadap mobile banking.

3. Persepsi nasabah atas Kemampuan akses berpengaruh positif signifikan moderat terhadap mobile banking. 
4. Persepsi nasabah atas Kemudahan penggunaan dan Manfaat tidak berpengaruh signifikan terhadap penggunaan mobile bnaking.

\section{Saran}

Dengan adanya beberapa keterbatasan penelitian di atas, saran bagi penelitian selanjutnya, yaitu:

1. Menambahkan variabel lain sebagai pengganti variabel persepsi kemudahan dan persepsi manfaat.

2. Menambahkan pernyataan mengenai penilaian risiko waktu pada variabel risiko.

3. Perlu ditambahkan pernyataan mengenai jaminan bahwa bank tidak akan melakukan penyalahgunaan terhadap kerahasiaan informasi nasabah.

\section{DAFTAR PUSTAKA}

Amalia, Rizky. 2009. Persepsi Mahasiswa Terhadap Pengguna Mobile banking Di Yogyakarta, Skripsi Sarjana Strata I, tidak diterbitkan, Yogyakarta: Fakultas Ekonomi UII.

Amijaya, Gilang Rizky. 2010. Pengaruh Faktor-faktor Risiko dan Kepercayaan dalam Penerimaan Nasabah Terhadap Penggunaan Mobile banking di Makassar, Skripsi Sarjana Strata I, tidak diterbitkan, Yogyakarta: Fakultas Ekonomi UII.

Auliani, Nur. 2008. Analisa Pengaruh Kepercayaan dan Risiko terhadap Minat Nasabah Bank dalam Menggunakan Layanan Mobile banking, Skripsi Sarjana Strata I, tidak diterbitkan, Yogyakarta: Fakultas Ekonomi UII.

Davis, F. D. 1989. "Perceived Usefulness, Perceived Ease of Use, and User Acceptance of Information Technology". MIS Quarterly 13 (3), 319-339.
George, D., dan Mallery, P. 2003. SPSS for Windows step by step: A simple guide and reference. (4th ed.). Boston: Allyn $\&$ Bacon.

Hadi, Syamsul. 2009. Metodologi Penelitian Kuantitatif untuk Akuntansi dan Keuangan, Yogyakarta: Ekonisia.

Herna, Kemala. 2009. Pengujian Tingkat Keamanan dan Privasi Individual dan Pengaruhnya terhadap Keinginan untuk Menggunakan Mobile banking, Skripsi Sarjana Strata I, tidak diterbitkan, Yogyakarta: Fakultas Ekonomi UII.

http://id.wikipedia.org/wiki/Teknologi informasi Karahanna, Elena; Straub, Detmar; and Chervany, Norman. 1999. "Information Technology Adoption Across Time: A Cross-Sectional Comparison of PreAdoption and Post-Adoption Beliefs". MIS Quarterly, 23 (2).

Maharsi, Sri dan Fenny. 2006. "Analisa Faktorfaktor yang Mempengaruhi Kepercayaan dan Pengaruh Kepercayaan Terhadap Loyalitas Pengguna Mobile banking di Surabaya". Jurnal Akuntansi dan Keuangan, Vol. 8 (1), Mei 2006, 35-51.

Negash. S. et al. 2003. "The impact of quality on Web-based customer support system effectiveness". Information \& Management 40, 757-768.

Pribadi, Angga Arianto. 2010. Analisa Skala Kualitas Layanan Mobile Value-Added Services, Skripsi Sarjana Strata I tidak diterbitkan, Jakarta: Fakultas Tehnik UI.

Rahadianto, Henry Aditya. 2009. Pengaruh Faktor Kepercayaan dan Risiko terhadap Pemakaian Teknologi Mobile banking di Bali, Skripsi Sarjana Strata I, tidak diterbitkan, Yogyakarta: Fakultas Ekonomi UII. 
Rahmawati, Yulia. 2010. Pengaruh Persepsi Kemudahan Penggunaan, Persepsi Manfaat dan Kepercayaan Konsumen Terhadap Pengaplikasian Layanan Mobile banking, Skripsi Sarjana Strata I, tidak diterbitkan, Yogyakarta: Fakultas Ekonomi UII.

Riganaldhy, Gerry. 2009. Analisis Faktor-faktor yang Mempengaruhi Trust Pengguna Mobile banking Di Indonesia, Skripsi Sarjana Strata I, tidak diterbitkan, Yogyakarta: Fakultas Ekonomi UII.

Rosita, Deviana. 2011. Faktor-faktor yang Mempengaruhi Pertimbangan Nasabah dalam Pengambilan Keputusan untuk Menggunakan Layanan Mobile banking, Skripsi
Sarjana Strata I, tidak diterbitkan, Yogyakarta: Fakultas Ekonomi UII.

Tan, Margaret dan Teo, Thompson S.H. 2000. "Factors Influencing the Adoption of Internet Banking". Journal of the Association for Information Systems, Vol. 1 (1), Article 5.

Wijanarko, Bondan Aditya. 2009. Faktor-faktor yanh Berpengaruh Terhadap Minat Nasabah untuk Menggunakan Mobile banking di Magelang, Skripsi Sarjana Strata I, tidak diterbitkan, Yogyakarta: Fakultas Ekonomi UII. 